\title{
Efficacy of Geotextile Jute Mulches on Yield, Soil Nutrient Dynamics and Weed Suppression in French bean (Phaseolus vulgaris L.)-Capsicum (Capsicum annum L.) Cropping System
}

\author{
Sai Parasar Das ${ }^{1 *}$, Monisanker Bera ${ }^{1}$, Jibanjit Sen², Goutam Kumar Ghosh ${ }^{1}$, Biplab Saha ${ }^{3}$, Sanjay Debnath ${ }^{3}$, S. B. Roy ${ }^{3}$, \\ Debabrata Das ${ }^{3}$, Suchhanda Mondal ${ }^{1}$, Pabitra Kumar Biswas ${ }^{1}$ and Manik Chandra Kundu ${ }^{1}$
}

${ }^{1}$ Dept. of Soil Science and Agricultural Chemistry, Institute of Agriculture, Visva-Bharati, Sriniketan, West Bengal (731 236), India

${ }^{2}$ ICAR-KVK, Keonjhar, Odisha University of Agriculture and Technology, Bhubaneswar, Odisha (751 003), India

${ }^{3}$ ICAR-NIR on Jute and Allied Fibre Technology, 12, Regent Park, Kolkata, West Bengal (700 040), India

\section{Corresponding Author}

Sai Parasar Das

e-mail: saiparasardas28@gmail.com

\author{
Article History \\ Manuscript No. AR1763 \\ Received in $30^{\text {th }}$ Dec, 2016 \\ Received in revised form $24^{\text {th }}$ Jan, 2017 \\ Accepted in final form $7^{\text {th }}$ Feb, 2017
}

\begin{abstract}
Field experiments conducted on french bean (Phaseolus vulgaris L.) during rabi season (December to March) of 2013 revealed that a significant increase in pod yield, available soil nutrients were resulted from the application of biodegradable geotextile jute mulches of varying thickness (250, 300, 350, 400 and 500 gsm sheets). Highest pod yield of french bean was recorded in the thicker mulched plots i.e. in 500 gsm and 400 gsm jute mulches. Weed population was also successfully controlled by these jute mulches as these mulches were initially very hard to penetrate. In overall performance, higher weed control efficiency and lower weed index were resulted from mulched plots of varying thickness than bare soil. Regarding nutrient dynamics; soil organic matter pool, available nitrogen, phosphorus and potassium content were found to be significantly higher than normal non-mulched plot. The residual effect on capsicum during 2014 revealed overall increment of soil organic stocks and others nutrient pool. Yield of residual crop chilli was higher in the plots which were previously mulched. From nutrient status to weed control efficiency point of view 500 and 400 gsm mulch were found to be superior then jute mulches of other thickness.Geotextile mulch could be a viable ecofriendly technology which has enormous potential to play a key role in increasing the carbon stocks and increasing the crop yield due to suppression of weeds, and improvement of soil health particularly in dry-land agriculture.
\end{abstract}

Keywords: Geotextile, nutrients, soil nutrients dynamics, weed control efficiency

\section{Introduction}

Geotextiles or Textile mulches are permeable fabrics made from polypropylene or bio-degradable materials like jute and other fabrics. These come in three basic forms: woven (resembling mail bag sacking), needle punched, or heat bonded. Organic amendments are also used as mulching materials (Quilty and Cattle, 2011; Diacono and Montemurro, 2010). Mulching with synthetic (polyethylene film) or organic (crop residue) materials has been widely practiced in the production of commercial crops and vegetables including tomato, lettuce, and other vegetables (Albert et al., 2010). The covering of the geo-textile mulches protect the soil from heavy raindrop impact and reduce the erosivity, velocity of runoff and wind by forming water stable aggregates (Wilson et al., 2009). Dry areas where insufficient rain prevents the establishment of a ground cover before the onset of heavy rain or strong winds or where a cover crop competes for moisture with the main crop it is most useful as an alternative to cover crops (Garcia et al., 2010). Textile mulching is a technique used to control weeds and more importantly, to prevent loss of soil moisture and promotes seedling establishment (Bu et al., 2013) mainly by reducing the soil surface exposure to direct solar radiation. This is particularly important in dry lands, where drought is frequent (Bezborodov et al., 2010). Mulching affects soil organic matter (SOM) through decomposition and soil moisture preservation (Jordan et al., 2011). The materials used in organic mulches contain a high percentage of organic matter (Quilty and Cattle, 2011) which can be incorporated in soil and improve soil properties including the size and activity of the soil microbial community (Doran, 1980; Manojlovic et al., 2010). There is little information regarding the effects of various mulching practices on nutrient use efficiency (NUE) and $\mathrm{N}$ dynamics (Azeez and Van Averbeke, 2010; Sharma and Behera, 2009). Understanding the accumulation and utilization of plant $\mathrm{N}$ and the associated soil mineral $\mathrm{N}$ dynamics under mulching conditions are essential to help guide further improvements in crop yield and $\mathrm{N}$ management strategies 
of dry land agriculture. In view of the above considerations field experiments were undertaken with the objectives to study the effect of geo-textile jute mulches on yield of french bean (Phaseolus vulgaris L.) and its residual effect on yield of capsicum (Capsicum annum L.) with emphasizing on the availability of major plant nutrients and its efficacy in controlling weed population in dryland areas.

\section{Materials and Methods}

\subsection{Experimental site}

The field experiments were conducted at the Agricultural Research Farm, Institute of Agriculture, Visva-Bharati University, Sriniketan $\left(23^{\circ} 39^{\prime} \mathrm{N}\right.$ and $\left.87^{\circ} 42^{\prime} \mathrm{E}\right)$, West Bengal, India on French bean (Phaseolus vulgaris L.) during December 2013 to March 2014 and Capsicum (Capsicum annum L.) crop was grown as residual crop during November 2014 to March 2015. The jute mulches were allowed to get decomposed in between these two crops. The experiments were conducted in a typical lateritic soil (Typic ochraqualf) of order Alfisol. The soil was sandy loam, acidic in nature $(\mathrm{pH} \mathrm{4.9)}$ and low in organic C $(0.38 \%)$, available $\mathrm{N}\left(129.5 \mathrm{~kg} \mathrm{ha}^{-1}\right)$, available $\mathrm{P}(22$ $\left.\mathrm{kg} \mathrm{ha}^{-1}\right)$, available $\mathrm{K}\left(100.8 \mathrm{~kg} \mathrm{ha}^{-1}\right)$, and available $\mathrm{S}(3.2 \mathrm{mg}$ $\left.\mathrm{kg}^{-1}\right)$. The jute mats were previously prepared by National Institute of Research on Jute and Allied Fibre Technology (ICAR), Kolkata, West Bengal, India. Small holes were made in those mats according to crop spacing for proper placing of seeds/seedlings. Experiments were laid out in Randomized Block Design with four replications in $4 \times 2.5 \mathrm{~m}^{2}$ plots and plant spacing of $40 \times 25 \mathrm{~cm}^{2}$. The treatments comprised of different thickness of jute mulch prepared by ICAR - NIRJAFT, Kolkata viz., $250 \mathrm{gsm}\left(T_{2}\right), 300 \mathrm{gsm}\left(T_{3}\right), 350 \mathrm{gsm}\left(T_{4}\right), 400 \mathrm{gsm}\left(T_{5}\right)$, $500 \mathrm{gsm}\left(\mathrm{T}_{6}\right)$ along with no mulched plot $\left(\mathrm{T}_{1}\right)$ without having any mulch. The pod weights recorded from the harvested samples of the net area earmarked for yield estimation were used for determining the grain yield in $\mathrm{kg} \mathrm{ha}^{-1}$.

\subsection{Chemical analysis}

The soil texture and $\mathrm{pH}$ (1:2; soil:water) were measured as per Bouyoucos (1951); Jackson (1973) respectively. Soil organic carbon was determined by wet digestion method of Walkley and Black (1934) as described by Jackson (1973). Available soil nitrogen was estimated by alkaline potassium permanganate method as outlined by Subbaiah and Asija (1956). Available phosphorus content of soil samples was estimated by Bray's No. 1 method (Bray and Kurtz, 1945) using spectrophotometer. Available potassium of soil samples was determined in soil: neutral normal ammonium acetate extract (1:5) of the soil using flame photometer (Jackson, 1973). Available sulphur in the soil was extracted using $0.15 \%$ calcium chloride $\left(\mathrm{CaCl}_{2}\right)$ solution (Williams and Steinbergs, 1959).

\subsection{Biometric observation on weeds}

The experimental field was infested with three categories of weeds. Cynodon dactylon among grasses; Tridex procumbens and Ludwigia parviflora among broad-leaved and Cyperus rotundus and Cyperus difformis among sedges. Records on population and biomass production were taken at 30 and 60 DAS. Population of different categories of weeds were recorded at 30 and 60 DAS by placing the quadrant of $25 \times 20$ $\mathrm{cm}^{2}\left(0.05 \mathrm{~m}^{2}\right)$ randomly in the sampling area. The values were converted to population $\mathrm{m}^{-2}$. Counts of grasses, broad leaved and sedge weeds were separately taken and their sum was used to obtain total weed population. Weeds were cleaned by washing, kept in sunlight for few hours and were kept in a hot air oven for drying at $72{ }^{\circ} \mathrm{C}$ for 72 hours or more till constant weights were recorded. Samples were kept in desiccators for cooling in dehumidified condition and their dry weight was recorded with an electronic balance. Weed control efficiency was calculated using the population of weeds. It was worked out from reduction in weed population due to weed control method over unweeded check by using the following formula and expressed in percentage.

Where,

WCE $=$ Weed control efficiency

WPC $=$ Weed population in control plot

WPT $=$ Weed population in treated plot

$W C E=\frac{W P C-W P T}{W P C} \times 100$

Weed index was determined by using the following formula and expressed in terms of percentage.

Where, WI=Weed index

$Y_{W F C}=$ Average yield of the crop in weed free check

$Y_{T}=$ Average yield of the crop in plot under treatment

$W I=\frac{Y_{W F C}-Y_{T}}{Y_{W F C}} \times 100$

\subsection{Statistical analysis and interpretation of data}

The data collected from the experiment at different growth stages were subjected to statistical analyses as described by Gomez and Gomez (1984). The level of significance used in " $F$ " and " $t$ " test was $p=0.05$. Critical difference values were calculated wherever the " $\mathrm{F}$ " test was significant.

\section{Results and Discussion}

\subsection{Soil nutrient status}

\subsubsection{Organic carbon}

The result of the experiment indicated that the thickness of the mulch had significant effect on organic matter status of soil. At 30 DAS, the highest organic carbon content was recorded in treatment having $500 \mathrm{gsm}$ mulch and was significantly greater than all other treatments except the treatment $350 \mathrm{gsm}$ mulch and $400 \mathrm{gsm}$ mulch with which it was statistically at par. The lowest organic carbon content $(0.38 \%)$ was observed in no mulch. Similar trend was observed at 60 DAS of the crop. The highest level of soil organic carbon content $(0.68 \%)$ was found in treatment having $500 \mathrm{gsm}$ mulch which was statistically at par with treatment $400 \mathrm{gsm}$ mulch and $350 \mathrm{gsm}$ mulch 
and was significantly greater than all other treatments. The minimum value was obtained from no mulch plot which was statistically at par with treatment $250 \mathrm{gsm}$ mulch and significantly lower than all other the treatments. Even in 90 DAS of the crop the highest level of soil Organic Carbon Content $(0.72 \%)$ was found in 500 gsm Mulch and treatment 400 gsm whereas the lowest level $(0.30 \%)$ was recorded in the no mulch treatment. The increase of organic carbon in the geo-textile jute mulch treatments under consideration was probably a consequence of the organic material added with exhausted mulch. Similar observation was recorded for the increase of organic carbon by Jordan et al., (2011) (Table 1)

\subsubsection{Available nitrogen}

The maximum available nitrogen level (177.46 $\left.\mathrm{kg} \mathrm{ha}^{-1}\right)$ at 30 DAS was found in treatment 500 gsm, which was statistically at par with the geo-textile mulch treatments, $400 \mathrm{gsm}$ and 350 gsm, respectively. The minimum value (137.59 $\mathrm{kg} \mathrm{ha}^{-1}$ ) was recorded in no mulch plot which was statistically at par with treatment 250 gsm mulch and 300 gsm mulch. Similar trend was observed at 60 DAS of the crop French bean. The highest level (185.12 $\mathrm{kg} \mathrm{ha}^{-1}$ ) was registered in treatment having 500 gsm geo-textile mulch which was statistically at par with treatment 400 gsm geo-textile mulch and significantly greater than all other treatments. The minimum value was obtained from no mulched which was statistically at par with treatment 250 gsm mulch and significantly lower than all other treatments. At the time of harvest the highest availability of nitrogen (179.72 $\mathrm{kg} \mathrm{ha}^{-1}$ ) was recorded with the treatment of 500 gsm mulch which was statistically at par with $400 \mathrm{gsm}$ mulch and $350 \mathrm{gsm}$ mulch. The lowest available Nitrogen (128.56 kg ha-1) was recorded in no mulch which was statistically at par with treatment $250 \mathrm{gsm}$ mulch and was significantly lower than all other treatments. Soil available nitrogen is closely related with plant uptake and optimum soil moisture availability. In dryland areas, in addition to the direct restrictions on crop growth, water deficit can also indirectly decreases soil nitrogen availability (Bu et al., 2013).

\subsubsection{Available phosphorus}

At 30 DAS highest Phosphorus (48.19575 kg ha-1) was obtained from 500 gsm thick jute mulch was applied and it was significantly greater than all other treatments and statistically at par with treatment $400 \mathrm{gsm}$. Lowest value (31.127 kg ha-1) was observed in no mulch and was significantly lower than all other the treatments. It was recorded that at 60 DAS the maximum amount of available Phosphorus (54.90 kg ha-1) was in treatment 500 gsm Mulch and it was statistically at par with treatment 400 gsm Mulch and treatment 350 gsm Mulch and significantly higher than all other treatments. The lowest amount of available Phosphorus (32.985 kg ha-1) was in no mulched plot. Even at 90 DAS highest Phosphorus (157.17 $\mathrm{kg} \mathrm{ha}^{-1}$ ) was obtained from 500 gsm mulched plot which was statistically at par with 400 gsm mulch and 350 gsm mulch. The minimum value $\left(29.96 \mathrm{~kg} \mathrm{ha}^{-1}\right)$ was obtained from no mulch which was significantly lower than all other

Table 1: Organic carbon, available nitrogen, available phosphorus, available potassium content of soil and yield of french bean as affected by geo-textile jute mulches

\begin{tabular}{|c|c|c|c|c|c|c|c|c|c|c|c|c|c|}
\hline \multirow[t]{3}{*}{$\begin{array}{l}\text { Treat- } \\
\text { ments }\end{array}$} & \multicolumn{3}{|c|}{$\begin{array}{c}\text { Organic carbon } \\
(\%)\end{array}$} & \multicolumn{3}{|c|}{$\begin{array}{c}\text { Available N } \\
\left(\mathrm{kg} \mathrm{ha}^{-1}\right)\end{array}$} & \multicolumn{3}{|c|}{$\begin{array}{l}\text { Available } \mathrm{P}_{2} \mathrm{O}_{5} \\
\left(\mathrm{~kg} \mathrm{ha}^{-1}\right)\end{array}$} & \multicolumn{3}{|c|}{$\begin{array}{c}\text { Available } \mathrm{K}_{2} \mathrm{O} \\
\left(\mathrm{kg} \mathrm{ha}^{-1}\right)\end{array}$} & \multirow[t]{3}{*}{$\begin{array}{c}\text { Yield } \\
\left(\mathrm{kg} \mathrm{ha}^{-1}\right)\end{array}$} \\
\hline & 30 & 60 & 90 & 30 & 60 & 90 & 30 & 60 & 90 & 30 & 60 & 90 & \\
\hline & DAS & DAS & DAS & DAS & DAS & DAS & DAS & DAS & DAS & DAS & DAS & DAS & \\
\hline $\begin{array}{l}\text { No } \\
\text { mulch }\end{array}$ & 0.38 & 0.39 & 0.30 & 137.59 & 939.25 & 128.56 & 31.13 & 32.98 & 29.96 & 92.50 & 103.87 & 89.29 & 939.25 \\
\hline $\begin{array}{l}250 \text { gsm } \\
\text { mulch }\end{array}$ & 0.47 & 0.44 & 0.47 & 141.41 & 1317.5 & 136.65 & 36.89 & 38.02 & 32.83 & 112.76 & 118.24 & 107.43 & 1317.5 \\
\hline $\begin{array}{l}300 \mathrm{gsm} \\
\text { mulch }\end{array}$ & 0.53 & 0.52 & 0.56 & 154.63 & 1608 & 145.54 & 39.14 & 38.91 & 37.21 & 118.65 & 133.08 & 114.94 & 1608 \\
\hline $\begin{array}{l}350 \text { gsm } \\
\text { mulch }\end{array}$ & 0.60 & 0.62 & 0.61 & 160.90 & 1731.25 & 165.06 & 39.816 & 49.73 & 45.06 & 132.91 & 140.87 & 122.80 & 1731.25 \\
\hline $\begin{array}{l}400 \text { gsm } \\
\text { mulch }\end{array}$ & 0.65 & 0.64 & 0.68 & 166.36 & 1995.5 & 168.14 & 44.34 & 50.06 & 45.29 & 134.63 & 170.20 & 144.87 & 1995.5 \\
\hline $\begin{array}{l}500 \text { gsm } \\
\text { mulch }\end{array}$ & 0.67 & 0.68 & 0.72 & 177.46 & 3215.25 & 179.72 & 48.19 & 54.90 & 49.74 & 146.42 & 185.12 & 157.17 & 3215.25 \\
\hline SEm \pm & 0.024 & 0.020 & 0.019 & 5.676 & 127.1589 & 5.480 & 1.535 & 1.777 & 1.551 & 4.471 & 4.990 & 4.519 & 127.1589 \\
\hline $\begin{array}{l}C D \\
(p=0.05)\end{array}$ & 0.073 & 0.061 & 0.060 & 17.111 & 383.298 & 16.519 & 4.629 & 5.357 & 4.675 & 13.479 & 15.042 & 13.623 & 383.298 \\
\hline Initial & & 0.38 & & & 129.52 & & & 26 & & & 100.8 & & \\
\hline
\end{tabular}


the treatments. The increase in phosphorus level in mulched plot was in conformity with the results of Sharma and Parmar (1998). It showed that the moisture conservation was another factor contributing to increased phosphorus use efficiency.

\subsubsection{Available potassium}

Significant improvement in the status of available potassium in soil over no mulch was registered due to geo-textile mulches in French bean. At 30 DAS, the highest available Potassium (146.42 $\mathrm{kg} \mathrm{ha}^{-1}$ ) was recorded from plot where 500 gsm thick jute mulch (geo-textile) was applied and it was significantly greater than all other treatments and statistically at par with 350 gsm and 400 gsm mulched plot. The minimum available $\mathrm{K}\left(92.497 \mathrm{~kg} \mathrm{ha}^{-1}\right)$ was observed in the plot which was devoid of any mulch. There was an increasing trend in availability of Potassium with the increasing thickness of jute mulch application. Similar trend was observed at 60 DAS of the crop. Highest available Potassium (185.125 kg ha-1) was obtained from the plot with 500 gsm thick jute mulch and it was significantly higher than all other treatments and statistically at par with $400 \mathrm{gsm}$ jute mulch. Low available potassium (103.87 $\mathrm{kg} \mathrm{ha}^{-1}$ ) was observed in the no mulched plot which was devoid of any type of mulch and was statistically at par with plot having 250 gsm jute sheet. Even at 90 DAS, highest Potassium (157.175 kg ha-1) was obtained from treatment with 500 gsm mulch which was statistically at par with 400 gsm mulched plot. It is interesting to note that the availability of potassium was high at 60 DAS irrespective of treatments than 30 DAS and 90 DAS.

\subsection{Yield of french bean}

The lowest amount of yield was recorded in the no mulch plot (939.25 $\mathrm{kg} \mathrm{ha}^{-1}$ ) which was significantly lower than all other the treatments except treatment with $250 \mathrm{gsm}$ mulch with which it was statistically at par. Maximum yield (3215.25 kg ha-1) was recorded in $500 \mathrm{gsm}$ mulch plot which was statistically at par with treatment 300 gsm Mulch plot. As early as 1942, researchers found that mulched trees grow $67 \%$ better than that grows on bare soil (Hopp and Posey, 1942). Since then many others have shown yield increments of plants as a result of mulching with appropriate materials (Tilander and Bonzi. 1997 and van Nierop and White, 1958). The superiority of thicker bio-degradable mulch treatments over treatments of thinner or no mulch in our experiment might be due to the beneficial effect of increased moisture, increased organic matter and nutrient status with high weed control efficiency. This result was in accordance with the results of Verdu and Mas (2007).

\subsection{Weed density and population}

The lowest density of BLWs (0.707 no. $\left.\mathrm{m}^{-2}\right)$ at 30 DAS was found in Treatment with $300 \mathrm{gsm}$ Mulch, $350 \mathrm{gsm}$ Mulch, $400 \mathrm{gsm}$ Mulch and $500 \mathrm{gsm}$ Mulch and was significantly lower than all other the treatments. At 60 DAS the lowest density of BLWs (1.25 no. $\mathrm{m}^{-2}$ ) was in 500 gsm Mulched plot which was significantly lower than all other treatments. The highest weed density of BLWs both at 30 and 60 DAS was in no mulch plot due to non-availability of any type of mulching material. The density of sedges also followed more or less same pattern as that of BLWs. The highest density of sedges (4.27 no. $\mathrm{m}^{-2}$ ) was recorded at 30 DAS was in treatment with no mulch which increased to $42 \mathrm{no} / \mathrm{m}^{2}$ at $60 \mathrm{DAS}$. The lowest density of sedges at 30 DAS $\left(0.707\right.$ no. $\left.\mathrm{m}^{-2}\right)$ was found in treatment with 350 gsm Mulch, 400 gsm Mulch and 500 gsm Mulch plot, whereas at 60 DAS the lowest density was in Treatment with 500 gsm Mulch. Grasses also followed the same trend as BLWs and Sedges. The lowest density 0.707 no. $\mathrm{m}^{-2}$ ) at 30 DAS was recorded in treatment with $350 \mathrm{gsm}$ Mulch, $400 \mathrm{gsm}$ Mulch and $500 \mathrm{gsm}$ Mulch. Similar trend was also observed at 60 DAS, where the lowest density $\left(2.5 \mathrm{no} / \mathrm{m}^{2}\right)$ was in Treatment with 500 gsm Mulch which was significantly lower than all other treatments. The highest density (4.32 no. $\mathrm{m}^{-2}$ ) at 30 DAS was found in no mulch plot which increased to 43 no. $\mathrm{m}^{-2}$ at 60 DAS and was significantly greater than all other treatments. Mulching as a mean for landscape weed control is highly effective, though the mechanism(s) responsible for control are not completely understood for all mulch types. Nearly all mulches reduce light, which will stress existing weeds and prevent the germination of many weed species, especially those with small seeds. The physical bar emerging, though this effect is temporary and disappears as mulches decomposed. Additionally, the protected soil habitat created by the use of mulches can increase beneficial organisms that prey upon weeds or eat their seeds. The weed population in our experiment was significantly less in mulched treatment compared to the non-mulched one as the mulches reduced light, which stressed existing weeds and prevent the germination of many weed species, especially those with small seeds. The physical barrier created by mulches prevented weeds from emerging, though this effect was temporary and disappeared as mulches decomposed. The similar observation was registered by Wilen et al. (1999).

\subsection{Weed control efficiency (WCE) and weed index (WI)}

At 30 DAS Weed Control Efficiency for BLWs was highest in Treatment with 300 gsm Mulch, 350 gsm Mulch, 400 gsm Mulch and 500 gsm Mulch followed by 250 gsm Mulched plot and for both grasses and sedges. WCE was highest in 350 gsm Mulch, 400 gsm Mulch and 500 gsm Mulch followed by $300 \mathrm{gsm}$ Mulch and $250 \mathrm{gsm}$ Mulch. The trend of weed control efficiency at 60 DAS revealed a decreasing tendency on decreasing the thickness of geo-textile mulch. The highest WCE was observed in Treatment with 500 and 400 gsm mulch followed by 350 and 300 gsm mulch plot. The lowest WCE was observed in case of treatment with no mulch and with 250 gsm mulch due to high weed density. Lowest weed index (0\%) was recorded in treatment with 500 gsm mulch followed by $37.93 \%$ in 300 gsm mulch, $46.15 \%$ in 400 gsm mulch, $49.98 \%$ in 300 gsm mulch and $59.02 \%$ in 250 gsm mulch. Highest weed index (70.787\%) was observed in the treatment without having any mulch cover (Table 2 ). 


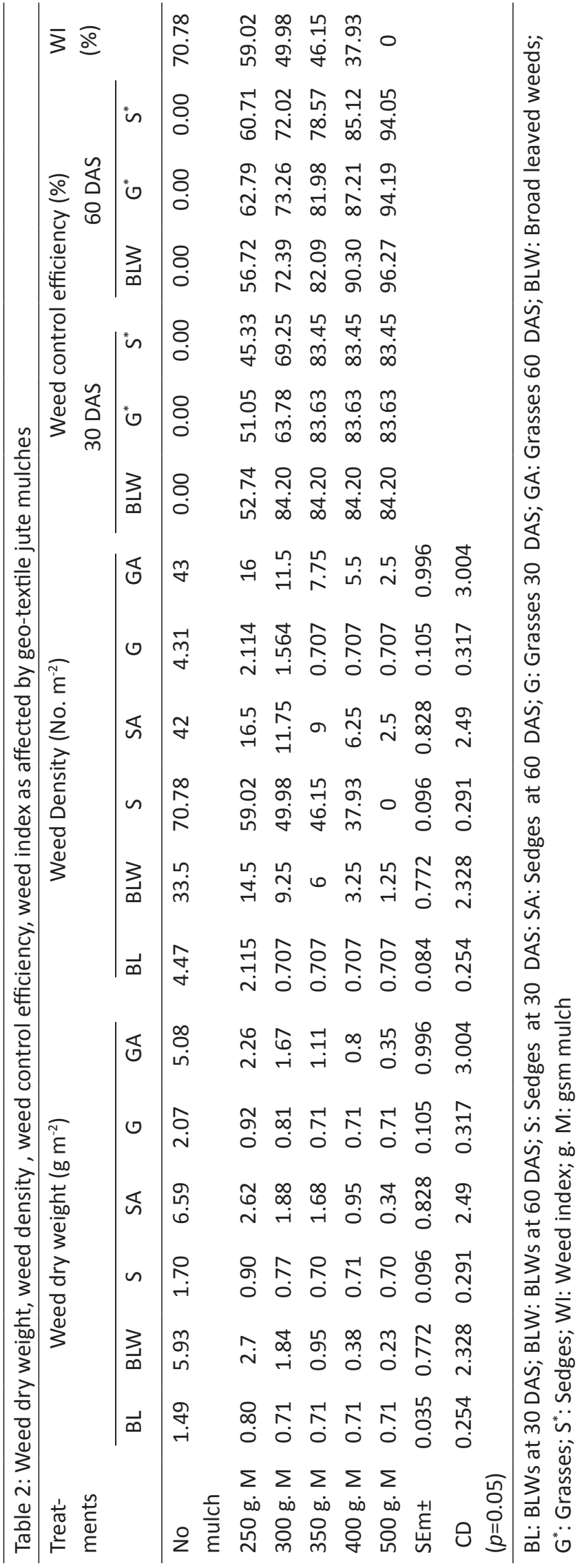

3.5. Residual effect of geo-textile jute mulches on Capsicum (Capsicum annum L.)

The highest Organic Carbon Content $(0.30825 \%)$ is recorded in Treatment having 500 gsm mulch and it was significantly greater than all other treatments except the treatment with $350 \mathrm{gsm}$ mulch and $400 \mathrm{gsm}$ mulch with which it was statistically at par. The lowest Organic Carbon Content $(0.1835 \%)$ was observed in no mulched plot which was significantly lower than all other the treatments. The highest nitrogen ( $51.816 \mathrm{~kg} \mathrm{ha}^{-1}$ ) was found in $500 \mathrm{gsm}$ Mulched plot which was significantly higher than all other the treatments (Table 3). The lowest amount of soil available Nitrogen (33.62 $\mathrm{Kg} \mathrm{ha}^{-1}$ ) was recorded in treatment with no mulch which was

Table 3: Residual effect of geo-textile mulches on available nitrogen, phosphorus, potassium, organic carbon and yield of chilli

\begin{tabular}{lccccc}
\hline $\begin{array}{l}\text { Treat- } \\
\text { ments }\end{array}$ & $\begin{array}{c}{ }^{*} \text { A Nitro- } \\
\text { gen } \\
\left(\mathrm{kg} \mathrm{ha}^{-1}\right)\end{array}$ & $\begin{array}{c}\mathrm{A} \\
\mathrm{P}_{2} \mathrm{O}_{5} \\
\left(\mathrm{~kg} \mathrm{~h}^{-1}\right)\end{array}$ & $\begin{array}{c}\mathrm{A} \\
\mathrm{K}_{2} \mathrm{O} \\
\left(\mathrm{kg} \mathrm{ha}^{-1}\right)\end{array}$ & $\begin{array}{c}\left.{ }^{* *} \mathrm{OC}\right) \\
(\%)\end{array}$ & $\begin{array}{c}\text { Yield } \\
(\mathrm{kg} \\
\left.\mathrm{ha}^{-1}\right)\end{array}$ \\
\hline $\begin{array}{l}\text { No } \\
\text { mulch }\end{array}$ & 33.62 & 36.28 & 94.15 & 0.18 & 4010.5 \\
$\begin{array}{l}250 \text { gsm } \\
\text { mulch }\end{array}$ & 40.39 & 37.40 & 106.15 & 0.23 & 4269 \\
$\begin{array}{l}300 \text { gsm } \\
\text { mulch }\end{array}$ & 42.14 & 39.90 & 117.76 & 0.26 & 4686 \\
$\begin{array}{l}350 \text { gsm } \\
\text { mulch }\end{array}$ & 42.91 & 40.74 & 125.98 & 0.28 & 5199 \\
$\begin{array}{l}400 \text { gsm } \\
\text { mulch }\end{array}$ & 44.97 & 45.72 & 130.87 & 0.28 & 6035.75 \\
$\begin{array}{l}500 \text { gsm } \\
\text { mulch }\end{array}$ & 51.81 & 50.21 & 137.05 & 0.30 & 10589 \\
$\begin{array}{l}\text { SEm } \pm \\
\text { CD }\end{array}$ & 2.285 & 1.729 & 5.460 & 0.009 & 311.30 \\
$(p=0.05)$ & 6.888 & 5.213 & 16.460 & 0.027 & 938.347 \\
\hline
\end{tabular}

${ }^{*}$ A: Available; ${ }^{* *} \mathrm{OC}$ : Organic carbon

at par with treatment having $300 \mathrm{gsm}$ Mulch. The lowest Phosphorus content ( $36.285 \mathrm{~kg} \mathrm{ha}^{-1}$ ) was noticed in $250 \mathrm{gsm}$ Mulch plot which was statistically at par with treatment having no mulch, 300 gsm mulch, 350 gsm mulch and significantly higher than all other the treatments. The highest Phosphorus content $\left(50.21 \mathrm{~kg} \mathrm{ha}^{-1}\right)$ was recorded in $500 \mathrm{gsm}$ mulched plot which was significantly higher than all other the treatments except treatment with 350 gsm mulch with which it was statistically at par. Similar trend was observed in case of soil available Potassium. The highest level (137.0515 kg ha-1) was found in the treatment having $500 \mathrm{gsm}$ mulch which was statistically at par with treatment with 350 gsm mulch and 400 gsm mulch and significantly greater than all other 
treatments. The minimum value $\left(94.15 \mathrm{~kg} \mathrm{ha}^{-1}\right)$ was obtained from no mulched plot which was statistically at par with treatment having $250 \mathrm{gsm}$ mulch \& significantly lower than all other the treatments. Organic mulches decompose over time and require periodic reapplications, but they provide organic matter and nutrients to the soil and enhance soil particle aggregation and water-holding capacity (Merwin et al., 1995, Verdu and Mas, 2007). In our experiment, geotextile jute mats of different thickness were used and French bean (Phaseolus vulgaris L.) was grown as direct crop and after biodegradation of geo-textile mats Capsicum (Capsicum annum L.) was grown as residual crop. The trend showed that the nutrient availability in Treatment having $500 \mathrm{gsm}$ mulch was higher than others as jute mulches decompose under appropriate water and temperature levels, nutrients are released into the soil and become available for root uptake or microbial use. The findings are in conformity with the findings of Chalker-Scott (2007). Highest yield of Capsicum was recorded in $500 \mathrm{gsm}$ mulched plot which was significantly higher than every other treatments.

\section{Conclusion}

The organic carbon pool was increased from $0.38 \%$ to $0.72 \%$ in $500 \mathrm{gsm}$ mulch. Available $\mathrm{N}, \mathrm{P}_{2} \mathrm{O}_{5}$ and $\mathrm{K}_{2} \mathrm{O}$ was increased from $129.52,26,100.8\left(\mathrm{~kg} \mathrm{ha}^{-1}\right)$ to $179.72,49.74,157.17\left(\mathrm{~kg} \mathrm{ha}^{-1}\right)$ respectively and higher yield of french bean and residual crop chilli $\left(6035.75 \mathrm{~kg} \mathrm{ha}^{-1}\right)$ was obtained in that treatment. Also higher weed control efficiency of $94.05 \%$ and zero weed index was recorded. So $500 \mathrm{gsm}$ mulch was found very effective among the geotextile jute mulches of other thickness.

\section{Acknowledgement}

We are thankful to ICAR- National Institute of Research on Jute and Allied Fibre Technology, Kolkata, India for providing geotextile jute mats and the partial financial assistance under 'Development, application and techno-economic analysis of crop specific agro-textiles' program to carry out the research work.

\section{References}

Albert, T., Karp, K., Starast, M., Paal, T., 2010. The effect of mulching and pruning on the vegetative growth and yield of the half-high blueberry. Agronomy Research $8,759-769$.

Azeez, J.O., Van Averbeke, W., 2010. Nitrogen mineralization potential of three animal manures applied on a sandy clay loam soil. Bioresource Technology 101, 5645-5651.

Bezborodov, G.A., Shadmanov, D.K., Mirhashimov, R.T., Yuldashev, T., Qureshi, A.S., Noble, A.D., Qadir, M., 2010. Mulching and water quality effects on soil salinity and sodicity dynamics and cotton productivity in Central Asia. Agriculture, Ecosystem and Environment 138, 95-102.
Bouyoucos, G.J., 1951. Hydrometer method improved for making particle size analysis of soils. Journal of Agronomy 54, 464.

Bray, R.H., Kurtz, L.T., 1945. Determination of total organic and available forms of phosphorus in soil. Soil Science 59, 39-45.

Bu, L.D., Liu J.L., Zhu, L., Luo, S.S., Chen, X.P., Li, S.Q., Hill, R.L., Zhao, Y., 2013. The effects of mulching on maize growth, yield and water use in a semi-arid region. Agricultural Water Management 123, 71-78.

Chalker-Scott, L., 2007. Impact of Mulches on Landscape Plants and the Environment-A Review. Journal of Environmental Horticulture 25(4), 239-249.

Diacono, M., Montemurro, F., 2010. Long term effects of organic amendments on soil fertility. A review. Agronomy for Sustainable Development 30, 401-422.

Doran, J.W., 1980. Microbial changes associated with residue management with reduced tillage. Soil Science Society of America Journal 44(3), 518-524.

Garcia, A., Persson, T., Guerra, L.C., Hoogenboom, G., 2010. Response of soybean genotypes to deficit irrigation regimes in a humid region of the southeastern USA. Agricultural Water Management 97, 981-987.

Gomez, K.A., Gomez, A.A., 1984. Statistical Procedure for Agricultural Research. A Willey-Interscience Publication, New York, 130-139.

Hopp, H., Posey, G.B., 1942. Evaluation of cork oak as a new farm tree crop in the southeastern United States. Bulletin of the Ecological Society of America 23, 73.

Jackson, M.L., 1973. Soil chemical analysis. Prentice Hall of India Pvt. Ltd New Delhi, 183-193.

Jordan, A., Zavala, L.M., Muoz-Rojas, M., 2011. Mulching, effects on soil physical properties. Encyclopedia of Agrophysics, Springer, Berlin, 492-496.

Manojlovic, M., Cabilovski, R., Bavec, M., 2010. Organic materials: sources of nitrogen in the organic production of lettuce. Turkish Journal of Agriculture and Forestry 34, 163-172.

Merwin, I.A., Rosenberger, D.A., Engle, C.A., Rist, D.L., Fargione, M., 1995. Comparing mulches, herbicides, and cultivation as orchard groundcover management systems. Hort Technology 5, 151-158.

Quilty, J.R., Cattle, S.R., 2011. Use and understanding of organic amendments in Australian agriculture: a review. Soil Research 49, 1-26.

Sharma A.R., Behera, U.K., 2009. Green leaf manuring with prunings of Leucaena leucocephala for nitrogen economy and improved productivity of maize (Zea mays)-wheat (Triticum aestivum) cropping system. Nutrient Cycling in Agroecosystem 86(1), 39-52.

Sharma, P.K., Parmar, D.K., 1998. The effect of phosphorus and mulching on the efficiency of phosphorus use and 
productivity of wheat grown on a mountain Alfisol in the Western Himalayas. Soil Use and Management 14, 25-29.

Subbaiah, B.V., Asija, G.L., 1956. A rapid procedure for the estimation of available nitrogen in soil. Current Science 25, 259-260.

Tilander, Y., Bonzi, M., 1997. Water and nutrient conservation through the use of agroforestry mulches, and sorghum yield response. Plant and Soil 197, 219-232.

van Nierop, E.T., White, D.P., 1958. Evaluation of several organic mulching materials on a sandy loam forest nursery soil. Journal of Forestry 56, 23-27.

Verdu, A.M., Mas, M.T., 2007. Mulching as an alternative technique for weed management in mandarin orchard tree rows. Agronomy for Sustainable Development 27, 367-375.

Walkley, A., Black, I.A., 1934. An Examination of Degtjareff
Method for Determining Soil Organic Matter and a Proposed Modification of the Chromic Acid Titration Method. Soil Science 37, 29-37.

Wilen, C.A., Schuch, U.K., Elmore, C.L., 1999. Mulches and sub irrigation control weeds in container production. Journal of Environmental Horticulture 17, 174-180.

Williams, C.H., Steinbergs, A., 1959. Soil sulphur fractions as chemical indices of available sulphur in some Australian soils. Australian Journal of Agricultural Research 10, 340-352.

Wilson, G.W.T., Rice, C.W., Rillig, M.C., Springer, A., Hartnett, D.C., 2009. Soil aggregation and carbon sequestration are tightly correlated with the abundance of arbuscular mycorrhizal fungi: results from long-term field experiments. Ecology Letters 12, 452-461. 